\title{
ANALISIS FAKTOR-FAKTOR YANG MEMPENGARUHI PENERIMAAN PAJAK (Studi Empirik di Kantor Pelayanan Pajak Pratama Surakarta)
}

\author{
Yuli Tri Cahyono ${ }^{1}$ \\ * Akuntansi, Fakultas Ekonomi dan Bisnis, Universitas Muhammadiyah Surakarta \\ *yuli_tricahyono@ums.ac.id ${ }^{l}$
}

This research is aimed to examine and analyze the influence of tax evasion, tax compliance by tax payer, self assessment system, awareness of tax payer, the comprehension on tax laws, and perceptions of service quality towards the level of tax income. The total sample of this research were 95 individual tax payers. The technique to collect sample in this research is convenience sampling. The data analysis method is multiple linear regression. The results of this research shows that the variable of perceptions of service quality give the influence towards the tax income, meanwhile the variable of tax evasion, tax compliance by tax payer, self assessment system, awareness of tax payer, the comprehension on tax laws are not influence towards the tax income.

Keywords: tax evasion, self assessment system, perceptions of service quality, the level of tax income

\section{Pendahuluan}

Pajak merupakan penerimaan negara terbesar, yang mana kurang lebih $65 \%$ penerimaan negara saat ini bersumber dari pajak. Dominasi pajak sebagai sumber penerimaan merupakan satu hal yang sangat wajar, terlebih ketika sumber daya alam khususnya minyak bumi tidak bisa lagi diandalkan. Dana yang digunakan untuk membiayai pembangunan yang disalurkan melalui kebijaksanaan pemerintah dalam anggaran belanja negara (APBN) antara lain berasal dari tabungan pemerintah, sehingga apabila sumber penerimaan negara yang akan membentuk tabungan pemerintah berkurang, maka sudah barang tentu dana yang digunakan untuk pelaksanaan pembangunan akan berkurang juga. Menurut penelitian Hermawati (2014) hal ini akan menghambat kelancaran pembangunan yang dilaksanakan oleh pemerintah dalam menunjang terwujudnya masyarakat adil dan makmur. Untuk itu upaya perwujudannya dalam menuju ke arah otonom yang nyata, dinamis, dan bertanggung jawab, antara lain perlu diimbangi dengan peningkatan penerimaan negara dari sektor pajak penghasilan $(\mathrm{PPh})$.

Upaya pemerintah untuk meningkatkan penerimaan dalam negeri dari sektor pajak, antara lain adalah dengan merubah sistem pemungutan pajak dari official assessment system menjadi self assessment system. Perubahan sistem ini memberikan kepercayaan kepada Wajib Pajak untuk melaporkan sendiri jumlah pajak yang seharusnya terutang. Dalam self assessment system ini Wajib Pajak-lah yang diberikan wewenang; kepercayaan; dan tanggungjawab untuk menghitung, memperhitungkan, membayar, dan melaporkan sendiri besarnya pajak yang harus dibayar. Keberhasilan self assessment system tidak akan tercapai tanpa adanya kerjasama antara petugas pajak dengan Wajib Pajak. Sistem ini akan berjalan baik apabila masyarakat memiliki tingkat kesadaran perpajakan secara sukarela (voluntary tax compliance) yang tinggi. Sebaliknya apabila tingkat kesadaran Wajib Pajak masih rendah, maka akan menimbulkan berbagai macam masalah, yang salah satunya adalah tax evasion.

Menurut penelitian Sari dan Afriyanti (2012) ketidakpatuhan Wajib Pajak dalam self assessment system dapat berkembang apabila tidak adanya ketegasan dari instansi perpajakan. Supaya Wajib Pajak tetap berada dalam koridor peraturan perpajakan, hal ini dapat diantisipasi dengan melakukan upaya intensifikasi pemeriksaan terhadap Wajib Pajak yang memenuhi kriteria untuk diperiksa. Pemeriksaan pajak dapat berdampak pada peningkatan penerimaan pajak pada Kantor Pelayanan Pajak (KPP) yang pada akhirnya pajak yang dibayarkan oleh Wajib Pajak akan masuk dalam kas negara.

Menurut penelitian Dewi dan Widuri (2013) kesadaran Wajib Pajak juga sangatlah diperlukan dalam meningkatkan penerimaan pajak, karena dalam membayar pajak, Wajib Pajak harus memiliki rasa kerelaan dan sukarela, serta harus menyadari bahwa manfaat sendiri adalah untuk kemajuan dan 
perkembangan negara kita sendiri. Apabila kesadaran masyarakat rendah, target pajak seringkali tidak terealisasi dengan baik dan benar. Penyebab kurangnya kesadaran dan kemauan untuk membayar pajak antara lain adalah adanya asas perpajakan bahwa hasil pemungutan pajak tidak langsung dinikmati oleh para Wajib Pajak.

Widodo (2010:284) menyatakan bahwa peningkatan kualitas dan kuantitas pelayanan diharapkan dapat meningkatkan kepuasan kepada Wajib Pajak sehingga mendorong kepatuhan dalam bidang perpajakan. Menurut penelitian Dewi dan Widuri (2013) terdapat beberapa faktor yang mempengaruhi tingkat kepatuhan Wajib Pajak, antara lain kondisi lingkungan yang tidak patuh pajak, pelayanan fiskus yang mengecewakan, tarip pajak yang dianggap terlalu tinggi, dan sistem administrasi perpajakan yang buruk. Dinas Pendapatan dan Keuangan harus melakukan upaya peningkatan kualitas dan kuantitas pelayanan yang diharapkan dapat meningkatkan kepuasan kepada Wajib Pajak sebagai pelanggan, sehingga persepsi Wajib Pajak terhadap kualitas pelayanan akan positif.

Penelitian ini adalah replikasi dari penelitian Dewi dan Widuri (2013) tentang faktor-faktor yang mempengaruhi keberhasilan penerimaan pajak daerah Kota Tarakan. Namun demikian terdapat beberapa perbedaan dengan penelitian sebelumnya tersebut dengan penelitian ini. Adapun perbedaan yang dimaksud, antara lain adalah:

a. Variabel yang digunakan dalam penelitian sebelumnya yaitu kesadaran Wajib Pajak, pemahaman Wajib Pajak terhadap peraturan perpajakan, dan persepsi Wajib Pajak terhadap kualitas pelayanan, sedangkan dalam penelitian ini ada penambahan variabel independen yang mempengaruhi penerimaan pajak, yaitu tax evasion, tingkat kepatuhan Wajib Pajak, dan self assessment system.

b. Penelitian sebelumnya mengambil lokasi penelitian di Kota Tarakan, sedangkan dalam penelitian ini di Kota Surakarta.

c. Penelitian sebelumnya dilakukan pada tahun 2013, sedangkan penelitian ini dilakukan pada tahun 2016.

Berdasarkan latar belakang tersebut, peneliti tertarik untuk melakukan penelitian tentang faktorfaktor yang berpengaruh terhadap penerimaan pajak.

\section{Kajian Pustaka dan Pengembangan Hipotesis Pustaka Pengertian Pajak}

Menurut Undang-Undang Nomor 28 Tahun 2007 tentang Ketentuan Umum dan Tata Cara Perpajakan, pajak adalah kontribusi wajib kepada negara yang terutang oleh orang pribadi atau badan yang bersifat memaksa berdasarkan Undang-Undang, dengan tidak mendapatkan imbalan secara langsung dan digunakan untuk keperluan negara bagi sebesarbesarnya kemakmuran rakyat. UU Nomor 4 Tahun 2012 Pasal 1 Angka 3 tentang Anggaran dan Belanja Negara mendefinisikan penerimaan perpajakan sebagai semua penerimaan negara yang terdiri atas pajak dalam negeri dan pajak perdagangan internasional. Besar/kecilnya penerimaan pajak sangat dipengaruhi oleh sistem yang diterapkan dalam pemungutan pajak, peraturan yang diterapkan, kualitas pelayanan di KPP, dan kondisi internal (kepribadian) Wajib Pajak, seperti tax evasion, tingkat kepatuhan, tingkat pemahaman terhadap isi peraturan perpajakan, kesadaran sebagai wajib pajak, dan persepsi terhadap kualitas pelayanan pajak.

\section{Tax Evasion}

Tax evasion diartikan sebagai suatu skema memperkecil pajak yang terutang dengan cara melanggar ketentuan perpajakan seperti tidak melaporkan sebagian penjualan atau memperbesar biaya dengan cara fiktif. Dengan demikian dari sisi hukum, tax evasion adalah termasuk dalam tindakan yang ilegal.

\section{Tingkat Kepatuhan Wajib Pajak}

Menurut penelitian Sari dan Afriyanti (2012) kepatuhan Wajib Pajak merupakan syarat agar penerimaan pajak negara meningkat. Dalam hal ini terdapat pengaruh positif antara tingkat kepatuhan Wajib Pajak terhadap peningkatan penerimaan pajak.

\section{Self Assessment System}

Menurut penelitian Dewi dan Widuri (2013) untuk pelaksanaan self assessment system, Wajib Pajak harus memiliki pemahaman terhadap peraturan perpajakan yang berlaku, sehingga Wajib Pajak dapat mengisi secara benar jumlah pajak terutang serta membayar pajak tepat pada waktunya tanpa ada tindakan pemaksaan, memasukkan, dan melaporkan 
pada waktunya informasi yang diperlukan sesuai dengan peraturan perpajakan yang berlaku yang dapat meningkatkan keberhasilan penerimaan pajak daerah.

\section{Kesadaran Wajib Pajak}

Menurut penelitian Dewi dan Widuri (2013) kesadaran perpajakan adalah suatu kondisi ketika seseorang mengetahui, mengakui, menghargai, dan menaati ketentuan perpajakan yang berlaku serta memiliki kesungguhan dan keinginan untuk memenuhi kewajiban perpajakannya.

\section{Pemahaman Wajib Pajak mengenai Peraturan Perpajakan}

Menurut penelitian Dewi dan Widuri (2013) pemahaman peraturan perpajakan adalah Wajib Pajak dapat memahami dan mengetahui tentang peraturan dan Undang-Undang serta tata cara perpajakan dan menerapkannya untuk melakukan kegiatan perpajakan seperti membayar pajak, melaporkan SPT, dan sebagainya.

\section{Persepsi Wajib Pajak mengenai Kualitas Pelayanan}

Pelayanan adalah urutan kegiatan yang terjadi dalam interaksi langsung antara seseorang yang orang lain atau mesin secara fisik, dan menyediakan kepuasan pelanggan. Jika dikaitkan dengan terminologi perpajakan, maka pelayanan dapat didefinisikan sebagai pelayanan dalam bentuk jasa di bidang perpajakan. Persepsi adalah proses yang digunakan individu mengelola dan menafsirkan kesan indera mereka dalam rangka memberikan makna kepada lingkungan mereka.

\section{Pengembangan Hipotesis \\ Pengaruh Tax Evasion terhadap Penerimaan Pajak} Menurut penelitian Putra et al (2011) banyak Wajib Pajak yang melakukan tax evasion dengan alasan karena banyaknya kasus korupsi yang terjadi di Indonesia, sehingga menimbulkan pemikiran Wajib Pajak bahwa beban pajak yang dibayarkan juga tidak akan masuk ke Kas Negara. Tidak mengherankan jika negara banyak berhutang, dan rakyat dirugikan karena pajak yang dibayarkan tidak dapat digunakan, melainkan dikorupsi, dan sisanya untuk membayar hutang negara. Secara matematis, semakin rendah tingkat tax evasion, maka akan semakin tinggi penerimaan negara. Hal ini menginspirasi rumusan hipotesis:

$\mathrm{H}_{1}$ : Tax Evasion berpengaruh terhadap tingkat penerimaan pajak oleh KPP Pratama Surakarta.

\section{Pengaruh Tingkat Kepatuhan Wajib Pajak terhadap Penerimaan Pajak}

Menurut penelitian Afriyanti (2012) kepatuhan Wajib Pajak merupakan syarat agar penerimaan pajak meningkat. Secara logika, semakin patuh Wajib Pajak melaporkan dan melunasi kewajiban perpajakannya, maka penerimaan pajak pada KPP akan meningkat. Hal ini menjadi dasar rumusan hipotesis:

$\mathrm{H}_{2}$ : Tingkat kepatuhan Wajib Pajak berpengaruh terhadap tingkat penerimaan pajak oleh KPP Pratama Surakarta.

\section{Pengaruh Self Assessment System terhadap Penerimaan Pajak}

Kepatuhan diperlukan dalam self assessment system dengan tujuan pada penerimaan pajak yang optimal. Masalah yang terjadi pada self assessment system yaitu adanya Wajib Pajak yang seharusnya menyampaikan SPT, tetapi ternyata enggan untuk membuat dan melaporkannya. Menurut penelitian Anggriawan (2015) self assessment system berpengaruh positif terhadap penerimaan pajak. Secara logika, semakin tinggi tingkat self assessment system, maka penerimaan pajak pada KPP akan meningkat.hal ini menjadi dasar rumusan hipotesis:

$\mathrm{H}_{3}$ : Self assessment system berpengaruh terhadap tingkat penerimaan pajak oleh KPP Pratama Surakarta.

\section{Pengaruh Kesadaran Wajib Pajak terhadap Penerimaan Pajak}

Menurut penelitian Dewi (2013) kesadaran Wajib Pajak berpengaruh terhadap pemungutan Wajib Pajak yang dapat dilihat dari tercapainya target Wajib Pajak yang dapat mempengaruhi keberhasilan penerimaan pajak. Semakin tinggi tingkat kesadaran Wajib Pajak, maka semakin tinggi pula tingkat penerimaan pajak pada KPP. Kesadaran akan perpajakan haruslah ditumbuhkan pada setiap Wajib Pajak agar mempunyai rasa kerelaan dalam memenuhi kewajibannya serta dapat berkontribusi terhadap penerimaan pajak yang akan dirasakan manfaatnya 
lewat kemajuan pembangunan daerah. Hal ini membentuk rumusan masalah:

$\mathrm{H}_{4}$ : Kesadaran Wajib Pajak berpengaruh terhadap tingkat penerimaan pajak oleh KPP Pratama Surakarta.

Pengaruh Pemahaman Wajib Pajak mengenai Peraturan Perpajakan terhadap Penerimaan Pajak Menurut penelitian Arisandy (2017) masih banyak Wajib Pajak yang belum paham secara terperinci terkait segala peraturan perpajakan yang ada dan masih banyak pula yang belum mampu untuk mengisi SPT-nya sendiri. Secara logika, semakin tinggi tingkat pemahaman Wajib Pajak mengenai peraturan perpajakan akan mendorong semakin besarnya pula tingkat penerimaan pajak pada KPP. Hal ini menjadi dasar rumusan hipotesis:

$\mathrm{H}_{5}$ : Tingkat pemahaman Wajib Pajak mengenai peraturan perpajakan berpengaruh terhadap tingkat penerimaan pajak oleh KPP Pratama Surakarta.

Pengaruh Persepsi Wajib Pajak mengenai Kualitas Pelayanan terhadap Penerimaan Pajak

Menurut penelitian Dewi (2013) hasil kualitas pelayanan yang diberikan merupakan hal yang dapat memberikan kepuasaan terhadap Wajib Pajak. Secara matematis, semakin tinggi persepsi kualitas pelayanan akan mengakibatkan maka semakin tinggi pula tingkat penerimaan pajak oleh negara. Ketentuan perpajakan yang telah ditetapkan dapat menjadi sumbangan terbesar penerimaan negara yang akan berakibat meningkatnya pembangunan. Dengan demikian dapat dirumuskan hipotesis:

$\mathrm{H}_{6}$ : Persepsi Wajib Pajak mengenai kualitas pelayanan berpengaruh terhadap tingkat penerimaan pajak oleh KPP Pratama Surakarta.

\section{Metode Penelitian}

\section{Jenis Penelitian}

Penelitian ini menggunakan jenis penelitian deskriptif kuantitatif, yaitu suatu penelitian yang menekankan pada pengujian teori-teori melalui pengukuran variabel penelitian dengan angka, melakukan analisis data dengan prosedur statistik, realitas bersifat obyektif, dan berdimensi tunggal. Di dalam penelitian ini hubungan atau pengaruh yang diteliti meliputi tax evasion, tingkat kepatuhan Wajib
Pajak, self assessment system, kesadaran Wajib Pajak, pemahaman Wajib Pajak mengenai peraturan pajak, dan persepsi Wajib Pajak mengenai kualitas pelayanan pada KPP Pratama Surakarta.

\section{Sampel dan Teknik Pengambilan Sampel}

Metode pengambilan sampel yang digunakan adalah metode convenience sampling, yaitu pengumpulan informasi dari anggota populasi yang secara senang hati bersedia memberikan informasi dan untuk memperoleh sejumlah informasi dasar secara cepat dan efisien.Teknik pemilihan sampel ini dipilih karena pertimbangan lokasi yang mudah untuk dijangkau sehingga dapat memudahkan peneliti dalam pengumpulan sampel yang akan digunakan dalam penelitian.

\section{Variabel dan Definisi Operasional Variabel Variabel Dependen \\ Penerimaan Pajak}

Tingkat penerimaan pajak adalah semua penerimaan negara yang terdiri atas pajak dalam negeri dan pajak perdagangan internasional. Variabel ini diukur dengan instrumen pengukuran dalam bentuk kuesioner dengan lima skala likert. Untuk setiap pemilihan responden atau jawaban diberi skor 5 untuk "Sangat Setuju (SS)," skor 4 untuk "Setuju (S)," skor 3 untuk "Netral (N)," skor 2 untuk "Tidak Setuju (TS)," dan skor 1 untuk "Sangat Tidak Setuju (STS)."

\section{Variabel Independen}

Tax Evasion

Tax Evasion adalah suatu skema memperkecil pajak yang terutang dengan cara melanggar ketentuan perpajakan seperti dengan cara tidak melaporkan sebagian penjualan atau memperbesar biaya dengan cara fiktif. Variabel ini diukur dengan instrumen pengukuran dalam bentuk kuesioner dengan lima skala likert. Untuk setiap pemilihan responden atau jawaban diberi skor 5 untuk "Sangat Setuju (SS)," skor 4 untuk "Setuju (S)," skor 3 untuk "Netral (N)," skor 2 untuk "Tidak Setuju (TS)," dan skor 1 untuk "Sangat Tidak Setuju (STS)."

\section{Tingkat Kepatuhan Wajib Pajak}

Menurut penelitian Adrianti (2013) tingkat kepatuhan Wajib Pajak adalah suatu keadaan ketika Wajib Pajak mampu memenuhi semua kewajiban perpajakan dan melaksanakan hak perpajakannya. 
Variabel ini diukur dengan instrumen pengukuran dalam bentuk kuesioner dengan lima skala likert. Untuk setiap pemilihan responden atau jawaban diberi skor 5 untuk "Sangat Setuju (SS)," skor 4 untuk "Setuju (S)," skor 3 untuk "Netral (N)," skor 2 untuk "Tidak Setuju (TS)," dan skor 1 untuk "Sangat Tidak Setuju (STS)."

\section{Self Assessment System}

Menurut Resmi (2003:27) self assessment system adalah sistem pemungutan pajak yang memberikan wewenang kepada Wajib Pajak untuk menentukan sendiri jumlah pajak terhutang setiap tahunnya sesuai dengan UU perpajakan yang berlaku. Variabel ini diukur dengan instrumen pengukuran dalam bentuk kuesioner dengan lima skala likert. Untuk setiap pemilihan responden atau jawaban diberi skor 5 untuk "Sangat Setuju (SS)," skor 4 untuk "Setuju (S)," skor 3 untuk "Netral (N)," skor 2 untuk "Tidak Setuju (TS)," dan skor 1 untuk "Sangat Tidak Setuju (STS)."

\section{Kesadaran Wajib Pajak}

Kesadaran Wajib Pajak adalah kesadaran untuk mematuhi ketentuan hukum perpajakan yang berlaku terkait ketentuan pajak dengan benar dan sukarela. Variabel ini diukur dengan instrumen pengukuran dalam bentuk kuesioner dengan lima skala likert. Untuk setiap pemilihan responden atau jawaban diberi skor 5 untuk "Sangat Setuju (SS)," skor 4 untuk "Setuju (S)," skor 3 untuk "Netral (N)," skor 2 untuk "Tidak Setuju (TS)," dan skor 1 untuk "Sangat Tidak Setuju (STS)."

\section{Pemahaman Wajib Pajak mengenai Peraturan Perpajakan}

Menurut penelitian Dewi dan Widuri (2013) yang dimaksud dengan pemahaman peraturan perpajakan adalah Wajib Pajak dapat memahami dan mengetahui tentang peraturan dan Undang-Undang serta tata cara perpajakan dan menerapkannya untuk melakukan kegiatan perpajakan seperti membayar pajak, melaporkan SPT, dan sebagainya. Variabel ini diukur dengan instrumen pengukuran dalam bentuk kuesioner dengan lima skala likert. Untuk setiap pemilihan responden atau jawaban diberi skor 5 untuk "Sangat Setuju (SS)," skor 4 untuk "Setuju (S)," skor 3 untuk "Netral (N)," skor 2 untuk "Tidak Setuju (TS)," dan skor 1 untuk "Sangat Tidak Setuju (STS)."

\section{Persepsi Wajib Pajak mengenai Peraturan Perpajakan}

Menurut Dewi (2013:32) kualitas pelayanan dapat diartikan sebagai sesuatu yang berhubungan dengan terpenuhnya harapan atau kebutuhan pelanggan. Pelayanan dikatakan berkualitas apabila dapat menyediakan produk atau jasa (pelayanan) sesuai dengan kebutuhan dan harapan. Variabel ini diukur dengan instrumen pengukuran dalam bentuk kuesioner dengan lima skala likert. Untuk setiap pemilihan responden atau jawaban diberi skor 5 untuk "Sangat Setuju (SS)," skor 4 untuk "Setuju (S)," skor 3 untuk "Netral (N)," skor 2 untuk "Tidak Setuju (TS)," dan skor 1 untuk "Sangat Tidak Setuju (STS)."

\section{Metode Analisis Data}

Pengujian hipotesis dilakukan dengan menggunakan metode analisis regresi berganda yang bertujuan untuk menguji apakah tax evasion, tingkat kepatuhan Wajib Pajak, self assessment system, kesadaran Wajib Pajak, pemahaman Wajib Pajak mengenai peraturan perpajakan, persepsi Wajib Pajak mengenai kualitas pelayanan berpengaruh terhadap penerimaan pajak. Sebelum dilakukan uji hipotesis, maka dilakukan uji asumsi klasik, yang meliputi uji normalitas, uji multikolinieritas, dan uji heterokedastisitas untuk menentukan kelayakan data untuk dipakai dalam analisis regresi. Selanjutnya dilakukan uji hipotesis menggunakan analisis regresi linier berganda untuk menyimpulkan terdukung atau tidaknya hipotesis. Adapun model persamaan regresinya adalah sebagai berikut.

$$
\begin{aligned}
& \mathrm{Y}=\alpha+\beta_{1} \mathrm{TE}+\beta_{2} \mathrm{TK}+\beta_{3} \mathrm{SAS}+\beta_{4} \mathrm{KWP}+\beta_{5} \mathrm{PPP}+\beta_{6} \\
& \mathrm{PTP}+\mathrm{e}
\end{aligned}
$$

\begin{tabular}{|c|c|}
\hline Y & $=$ Tingkat penerimaan pajak \\
\hline$\alpha$ & $=$ Konstanta \\
\hline$T E$ & $=$ Tax Evasion \\
\hline TK & $=$ Tingkat kepatuhan Wajib Pajak \\
\hline$S A S$ & $=$ Self Assessment system \\
\hline KWP & = Kesadaran Wajib Pajak \\
\hline PPP & $\begin{aligned}= & \text { Pemahaman Wajib Pajak terhadap } \\
& \text { peraturan pajak }\end{aligned}$ \\
\hline PTP & $\begin{aligned}= & \text { Persepsi terhadap kualitas } \\
& \text { pelayanan }\end{aligned}$ \\
\hline$\beta 1 \ldots \beta 6$ & $=$ Koefisien Regresi \\
\hline
\end{tabular}

Keterangan: 


\section{Hasil dan Pembahasan Deskripsi Data}

Penelitian ini dilakukan dengan menyebarkan kuesioner kepada responden yang terdaftar sebagai WPOP pada KPP Pratama Surakarta tahun 2016 yang terkait dengan faktor-faktor yang mempengaruhi penerimaan pajak. Data pokok dan data primer diperoleh dengan menggunakan metode survei secara langsung kepada responden dan hasil jawaban dari kuesioner diolah guna pengujian hipotesis. Penyebaran kuesioner pada WPOP yang terdaftar di KPP Pratama Surakarta terkait dengan faktor-faktor penerimaan pajak adalah sebagaimana terlihat pada tabel IV.1.

TABEL I

KRITERIA PENGAMBILAN SAMPEL

\begin{tabular}{lll}
\hline No & \multicolumn{1}{c}{ Keterangan } & \multicolumn{1}{c}{ Jumlah } \\
& & Sampel \\
\hline 1 & Sampel WPOP pada KPP Pratama Surakarta & 100 \\
2 & Kuesioner tidak kembali & 0 \\
3 & Kuesioner rusak atau tidak dapat dipakai & 0 \\
4 & Sampel yang dibuang (outlied sample) & $(5)$ \\
& Jumlah sampel penelitian & 95 \\
\hline
\end{tabular}

Sumber: Data primer diolah penulis, 2017

Tabel I menunjukkan jumlah kuesioner yang disebar sebanyak 100 kuesioner yang telah ditetapkan penulis. Kuesioner yang kembali sebanyak 100 kuesioner atau dengan tingkat pengembalian sebanyak $100 \%$, karena diisi dengan lengkap oleh responden. Namun demikian dikarenakan variabel tax evasion yang kurang reliabel, maka ada pembuangan sampel (outlied sample) sehingga jumlah sampel penelitian menjadi 95.

\section{Hasil Uji Validitas}

Hasil uji validitas menunjukkan bahwa semua item pernyataan untuk variabel tax evasion, tingkat kepatuhan Wajib Pajak, self assessment system, kesadaran Wajib Pajak, pemahaman Wajib Pajak mengenai peraturan perpajakan, persepsi Wajib Pajak mengenai kualitas pelayanan, dan penerimaan pajak mempunyai nilai probabilitas lebih kecil dari 0,05 . Dengan demikian semua item pernyataan untuk mengukur variabel dalam penelitian ini dinyatakan valid.

\section{Hasil Uji Reliabilitas}

TABEL II

HASIL UJI RELIABILITAS

\begin{tabular}{|c|c|c|}
\hline Variabel & $\begin{array}{l}\text { Cronbach's } \\
\text { Alpha }\end{array}$ & Keterangan \\
\hline Tax Evasion(TE) & 0,605 & Reliabel \\
\hline Tingkat Kepatuhan Wajib Pajak (TK) & 0,807 & Reliabel \\
\hline Self Assessment System (SAS) & - & - \\
\hline Kesadaran Wajib Pajak (KWP) & 0,683 & Reliabel \\
\hline $\begin{array}{l}\text { Tingkat Pemahaman } \\
\text { mengenai } \quad \text { Peraturan } \\
\text { (PPP) }\end{array}$ & 0,694 & Reliabel \\
\hline $\begin{array}{l}\text { Persepsi terhadap Kualitas Pelayanan } \\
\text { (PTP) }\end{array}$ & 0,905 & Reliabel \\
\hline Penerimaan Pajak (PP) & 0,678 & Reliabel \\
\hline
\end{tabular}

Sumber: Data primer diolah penulis, 2017

Dari hasil uji reliabilitas yang terlihat pada Tabel II dapat diperoleh bahwa seluruh item pernyataan dari masing-masing variabel dalam penelitian ini adalah reliabel. Hal ini ditunjukkan oleh nilai cronbach's alpha dari masing-masing variabel lebih dari 0,60. Menurut penelitian Phillips et al (1991) variabel yang instrumen pertanyaannya kurang dari tiga butir tidak perlu diuji reliabilitasnya. Adapun variabel self assessment system dalam penelitian ini hanya memiliki dua butir pertanyaan sehingga tidak perlu diuji reliabilitasnya.

\section{Uji Asumsi Klasik}

Hasil Uji Normalitas Data

TABEL III HASIL PENGUJIAN NORMALITAS

\begin{tabular}{cccc}
\hline Variabel & $\begin{array}{c}\text { Kolmogrov- } \\
\text { Smirnov }\end{array}$ & $\begin{array}{c}P \text { - } \\
\text { Value }\end{array}$ & Keterangan \\
\hline $\begin{array}{c}\text { Unstandardized } \\
\text { Residual }\end{array}$ & 0,560 & 0,912 & Normal \\
\hline
\end{tabular}

Sumber: Data primer diolah penulis, 2017

Hasil uji normalitas pada Tabel III menunjukkan nilai signifikansi ( $p$-value) sebesar 0,912 yang lebih besar dari 0,05. Dengan demikian dapat disimpulkan bahwa model regresi layak digunakan, karena memenuhi asumsi normalitas (data penelitian terdistribusi secara normal). 
Hasil Uji Multikolinearitas

TABEL IV

HASIL PENGUJIAN MULTIKOLINEARITAS

\begin{tabular}{|c|c|c|c|}
\hline Variabel & Tolerance & VIF & Keterangan \\
\hline Tax Evasion(TE) & 0,816 & 1,226 & $\begin{array}{c}\text { Tidak Terjadi } \\
\text { Multikolinearitas }\end{array}$ \\
\hline $\begin{array}{l}\text { Tingkat Kepatuhan } \\
\text { Wajib Pajak (TK) }\end{array}$ & 0,567 & 1,764 & $\begin{array}{c}\text { Tidak Terjadi } \\
\text { Multikolinearitas }\end{array}$ \\
\hline $\begin{array}{l}\text { Self Assessment System } \\
(\text { SAS) }\end{array}$ & 0,899 & 1,113 & $\begin{array}{c}\text { Tidak Terjadi } \\
\text { Multikolinearitas }\end{array}$ \\
\hline $\begin{array}{l}\text { Kesadaran Wajib Pajak } \\
\text { (KWP) }\end{array}$ & 0,727 & 1,375 & $\begin{array}{c}\text { Tidak Terjadi } \\
\text { Multikolinearitas }\end{array}$ \\
\hline $\begin{array}{l}\text { Tingkat Pemahaman } \\
\text { Wajib Pajak terhadap }\end{array}$ & 0,813 & 1,231 & $\begin{array}{c}\text { Tidak Terjadi } \\
\text { Multikolinearitas }\end{array}$ \\
\hline $\begin{array}{l}\text { Peraturan Perpajakan } \\
\text { (PPP) }\end{array}$ & & & \\
\hline Persepsi & 0,598 & 1,671 & Tidak Terjadi \\
\hline $\begin{array}{l}\text { Kualitas } \\
\text { (PTP) }\end{array}$ & & & Multikolinearitas \\
\hline
\end{tabular}

Sumber: Data primer diolah penulis, 2017

Berdasarkan Tabel IV terlihat bahwa masingmasing variabel bebas mempunyai nilai VIF lebih kecil dari 10 dan nilai tolerance lebih besar dari 0,1 . Hal ini menunjukkan bahwa tidak ada gejala multikolinearitas dalam model regresi, sehingga memenuhi syarat analisis regresi.

\section{Hasil Uji Heterokedastisitas}

TABEL V

HASIL UJI HETEROKEDASTISITAS

\begin{tabular}{|c|c|c|}
\hline Variabel & Sig & Simpulan \\
\hline Tax Evasion $(T E)$ & 0,948 & Tidak Terjadi \\
\hline $\begin{array}{l}\text { Tingkat Kepatuhan Wajib } \\
\text { Pajak (TK) }\end{array}$ & 0,334 & $\begin{array}{l}\text { Heterokedastisitas } \\
\text { Tidak Terjadi } \\
\text { Heterokedastisitas }\end{array}$ \\
\hline Self Assessment System (SAS) & 0,362 & $\begin{array}{c}\text { Tidak Terjadi } \\
\text { Heterokedastisitas }\end{array}$ \\
\hline $\begin{array}{l}\text { Kesadaran } \quad \text { Wajib } \\
\text { (KWP) }\end{array}$ & 0,095 & $\begin{array}{c}\text { Tidak Terjadi } \\
\text { Heterokedastisitas }\end{array}$ \\
\hline $\begin{array}{l}\text { Tingkat Pemahaman Wajib } \\
\text { Pajak terhadap Peraturan } \\
\text { Perpajakan (PPP) }\end{array}$ & 0,427 & $\begin{array}{c}\text { Tidak Terjadi } \\
\text { Heterokedastisitas }\end{array}$ \\
\hline $\begin{array}{l}\text { Persepsi terhadap Kualitas } \\
\text { Pelayanan (PTP) }\end{array}$ & 0,775 & $\begin{array}{c}\text { Tidak Terjadi } \\
\text { Heterokedastisitas }\end{array}$ \\
\hline
\end{tabular}

Sumber: Data primer diolah penulis, 2017
Berdasarkan Tabel V terlihat bahwa masingmasing variabel bebas memiliki nilai signifikansi lebih besar dari 0,05. Dengan demikian dapat disimpulkan bahwa setiap variabel tidak mengandung adanya heterokedastisitas, sehingga memenuhi persyaratan untuk analisis regresi.

\section{Uji Hipotesis}

Regresi Linear Berganda

TABEL VI

HASIL UJI REGRESI LINEAR BERGANDA

\begin{tabular}{lcccc}
\hline \multicolumn{1}{c}{ Model } & \multicolumn{2}{c}{$\begin{array}{c}\text { Unstandardized } \\
\text { Coefficients }\end{array}$} & $\mathrm{t}$ & Sig \\
& B & Std.Error \\
(Constant) & 29,481 & 5,559 & 5,303 & 0,000 \\
$T E$ & $-0,040$ & 0,122 & - & 0,743 \\
& & & 0,329 & \\
TK & 0,021 & 0,136 & 0,155 & 0,877 \\
SAS & $-0,305$ & 0,431 & - & 0,482 \\
& & & 0,707 & \\
KWP & 0,158 & 0,207 & 0,763 & 0,447 \\
PPP & 0,311 & 0,191 & 1,627 & 0,107 \\
PTP & 0,422 & 0,178 & 2,368 & 0,020 \\
\hline Sur
\end{tabular}

Sumber: Data primer diolah penulis, 2017

Dari tabel IV.17 yang merupakan hasil pengujian regresi linier berganda dapat ditulis persamaan model regresi sebagai berikut.

$\mathrm{PP}=29,481-0,040 T E+0,021 \mathrm{TK}-0,305 S A S+$

$0,158 \mathrm{KWP}+0,311 \mathrm{PPP}+0,422 \mathrm{PTP}+\mathrm{e}$

Berdasarkan persamaan regresi tersebut, dapat diinterpretasikan sebagai berikut:

1) Nilai konstanta sebesar 29,481 dengan parameter positif. Hal ini berarti bahwa apabila tax evasion (TE), tingkat kepatuhan Wajib Pajak (TK), self assessment system(SAS), kesadaran Wajib Pajak (KWP), tingkat pemahaman Wajib Pajak terhadap peraturan perpajakan (PPP), dan persepsi terhadap kualitas pelayanan (PTP) diasumsikan konstan atau sama dengan 0 , maka variabel nilai perusahaan yang diukur adalah sebesar 29,481.

2) Nilai koefisien regresi untuk variabel tax evasion adalah -0,040. Hasil ini menunjukkan bahwa apabila tax evasion meningkat, sedangkan variabel lainnya dianggap konstan, maka akan terjadi penurunan penerimaan pajak. Sebaliknya, jika terjadi penurunan tax evasion, maka akan berakibat kenaikan penerimaan pajak. 
3) Nilai koefisien regresi untuk variabel tingkat kepatuhan Wajib Pajak adalah $+0,021$. Hasil ini menunjukkan bahwa apabila tingkat kepatuhan Wajib Pajak meningkat, sedangkan variabel lainnya dianggap konstan, maka akan terjadi kenaikan penerimaan pajak. Sebaliknya, jika terjadi penurunan tingkat kepatuhan Wajib Pajak, maka akan terjadi penurunan penerimaan pajak.

4) Nilai koefisien regresi untuk variabel self assessment system adalah $-0,305$. Hasil ini menunjukkan bahwa apabila pelaksanaan self assessment system semakin konsisten, sedangkan variabel lainnya dianggap konstan, maka akan terjadi penurunan penerimaan pajak sebesar 30,5\%. Sebaliknya, jika pelaksanaan self assessment system semakin tidak konsisten, maka akan terjadi kenaikan penerimaan pajak.

5) Nilai koefisien regresi untuk variabel kesadaran Wajib Pajak adalah $+0,158$. Hasil ini menunjukkan bahwa apabila kesadaran Wajib Pajak semakin meningkat, sedangkan variabel lainnya dianggap konstan, maka akan terjadi kenaikan penerimaan pajak. Sebaliknya, jika kesadaran Wajib Pajak menurun, maka akan terjadi penurunan penerimaan pajak.

6) Nilai koefisien regresi untuk variabel tingkat pemahaman Wajib Pajak terhadap peraturan perpajakan adalah $+0,311$. Hasil ini menunjukkan bahwa apabila tingkat pemahaman Wajib Pajak terhadap peraturan perpajakan semakin baik, sedangkan variabel lainnya dianggap konstan, maka akan terjadi kenaikan penerimaan pajak. Sebaliknya, jika tingkat pemahaman Wajib Pajak terhadap peraturan perpajakan semakin rendah, maka akan terjadi penurunan penerimaan pajak.

Nilai koefisien regresi untuk variabel persepsi terhadap kualitas pelayanan adalah $+0,422$. Hasil ini menunjukkan bahwa apabila persepsi terhadap kualitas pelayanan meningkat, sedangkan variabel lainnya dianggap konstan, maka akan terjadi kenaikan penerimaan pajak. Sebaliknya, jika terjadi penurunan persepsi terhadap kualitas pelayanan, maka akan terjadi penurunan penerimaan pajak.

\section{Uji F (Uji Ketepatan Model)}

TABEL VII

HASIL UJI $F$-TEST

\begin{tabular}{lcccc}
\hline \multicolumn{1}{c}{ Model } & Squares & df & $\mathrm{F}_{\text {hitung }}$ & Sig \\
\hline Regression & 295,694 & 6 & 3,359 & 0,005 \\
Residual & 1291,190 & 88 & & \\
Total & 1586,884 & 94 & & \\
\hline
\end{tabular}

Sumber: Data primer diolah penulis, 2017

Berdasarkan Tabel VII dapat diperoleh bahwa nilai $\mathrm{F}_{\text {hitung }}$ sebesar 3,359 dengan tingkat signifikansi sebesar 0,005 lebih kecil dari 0,05. Hal ini menunjukkan bahwa model regresi yang digunakan sudah tepat (fit of goodness).

Uji t

TABEL VII

HASIL UJI T

\begin{tabular}{lccl}
\hline \multicolumn{1}{c}{ Variabel } & $\mathrm{t}_{\text {hitung }}$ & Sig & Keterangan \\
\hline $\begin{array}{l}\text { Tax Evasion (TE) } \\
\text { Tingkat Kepatuhan }\end{array}$ & $-0,329$ & 0,743 & $\mathrm{H}_{1}$ Ditolak \\
$\begin{array}{l}\text { Wajib Pajak (TK) } \\
\text { Self Assessment System }\end{array}$ & $-0,707$ & 0,477 & $\mathrm{H}_{2}$ Ditolak \\
$\begin{array}{l}\text { (SAS) } \\
\text { Kesadaran Wajib Pajak }\end{array}$ & 0,763 & 0,447 & $\mathrm{H}_{3}$ Ditolak \\
$\begin{array}{l}\text { KWP) Ditolak } \\
\text { Tingkat Pemahaman }\end{array}$ & 1,627 & 0,107 & $\mathrm{H}_{5}$ Ditolak \\
$\begin{array}{l}\text { Wajib Pajak terhadap } \\
\text { Peraturan Perpajakan } \\
\text { (PPP) }\end{array}$ & & & \\
$\begin{array}{l}\text { Persepsi terhadap } \\
\text { Kualitas Pelayanan }\end{array}$ & 2,368 & 0,020 & $\mathrm{H}_{6}$ Diterima \\
$(\mathrm{PTP}) \quad$ & & \\
\hline
\end{tabular}

Sumber: Data primer diolah penulis, 2017

Berdasarkan Tabel VIII dapat diuraikan tentang bagaimana pengaruh tiap-tiap variabel independen terhadap variabel dependen, sebagai berikut:

1) Pengaruh Tax Evasion Terhadap Penerimaan Pajak

Variabel tax evasion menunjukkan nilai $t_{\text {hitung }}$ sebesar -0,329 lebih kecil dari $t_{\text {tabel }}(1,661)$ dengan tingkat signifikansi sebesar 0,743 lebih besar dari $\alpha$ $=0,05$, sehingga $\mathrm{H}_{1}$ ditolak. Hasil ini menunjukkan bahwa tax evasion tidak berpengaruh terhadap penerimaan pajak.

2) Pengaruh Tingkat Kepatuhan Wajib Pajak Terhadap Penerimaan Pajak

Variabel tingkat kepatuhan Wajib Pajak menunjukkan nilai $t_{\text {hitung }}$ sebesar 0,155 lebih kecil 
dari $\mathrm{t}_{\text {tabel }}(1,661)$ dengan tingkat signifikansi sebesar 0,877 lebih besar dari $\alpha=0,05$, sehingga $\mathrm{H}_{2}$ ditolak. Hasil ini menunjukkan bahwa tingkat kepatuhan Wajib Pajak tidak berpengaruh terhadap penerimaan pajak.

3) Pengaruh Self Assessment System Terhadap Penerimaan Pajak

Variabel self assessment system menunjukkan nilai $\mathrm{t}_{\text {hitung }}$ sebesar $-0,707$ lebih kecil dari $\mathrm{t}_{\text {tabel }}(1,661)$ dengan tingkat signifikansi sebesar 0,482 lebih besar dari $\alpha=0,05$, sehingga $\mathrm{H}_{3}$ ditolak. Hasil ini menunjukkan bahwa self assessment system tidak berpengaruh terhadap penerimaan pajak.

4) Pengaruh Kesadaran Wajib Pajak Terhadap Penerimaan Pajak

Variabel kesadaran Wajib Pajak menunjukkan nilai $\mathrm{t}_{\text {hitung }}$ sebesar 0,763 lebih kecil dari $\mathrm{t}_{\text {tabel }}(1,661)$ dengan tingkat signifikansi sebesar 0,447 lebih besar dari $\alpha=0,05$, sehingga $\mathrm{H}_{4}$ ditolak. Hasil ini menunjukkan bahwa kesadaran Wajib Pajak tidak berpengaruh terhadap penerimaan pajak.

5) Pengaruh Tingkat Pemahaman Wajib Pajak Mengenai Peraturan Perpajakan Terhadap Penerimaan Pajak

Variabel tingkat pemahaman Wajib Pajak mengenai peraturan perpajakan menunjukkan nilai $\mathrm{t}_{\text {hitung }}$ sebesar 1,627 lebih kecil dari $\mathrm{t}_{\text {tabel }}(1,661)$ dengan tingkat signifikansi sebesar 0,107 memiliki nilai yang lebih besar dari $\alpha=0,05$, sehingga $\mathrm{H}_{5}$ ditolak. Hasil ini menunjukkan bahwa tingkat pemahaman Wajib Pajak mengenai peraturan perpajakan tidak berpengaruh terhadap penerimaan pajak.

6) Pengaruh Persepsi Kualitas Pelayanan Terhadap Penerimaan Pajak

Variabel persepsi kualitas pelayanan menunjukkan nilai $t_{\text {hitung }}$ sebesar 2,368 lebih besar dari $t_{\text {tabel }}$ $(1,661)$ dengan tingkat signifikansi sebesar 0,020 lebih kecil dari $\alpha=0,05$, sehingga $\mathrm{H}_{6}$ diterima. Hasil ini menunjukkan bahwa persepsi kualitas pelayanan berpengaruh terhadap penerimaan pajak.

Uji $\mathbf{R}^{2}$

TABEL IX
HASIL UJI KOEFISIEN DETERMINASI $\left(\mathrm{R}^{2}\right)$

\begin{tabular}{ccc}
\hline Model & $R^{2}$ & Adjusted $R^{2}$ \\
\hline Regression & 0,186 & 0,131 \\
\hline
\end{tabular}

Sumber: Data primer diolah penulis, 2017
Dari hasil perhitungan diperoleh nilai koefisien determinasi (adjusted $R^{2}$ ) sebesar 0,131. Hal ini berarti bahwa sebesar $13,1 \%$ variabel dependen yaitu penerimaan pajak dipengaruhi oleh variabel independen, sedangkan sisanya yaitu sebesar $86,9 \%$ dijelaskan oleh variabel lain di luar model.

\section{Pembahasan Hasil Penelitian}

\section{Pengaruh Tax Evasion Terhadap Penerimaan Pajak.}

Hasil penelitian menujukkan bahwa tax evasion tidak berpengaruh terhadap penerimaan pajak. Hal ini berarti tax evasion tidak memiliki kemampuan untuk mempengaruhi penerimaan pajak.

Tax Evasion secara umum bersifat melawan hukum (ilegal) dan mencakup perbuatan sengaja tidak melaporkan secara lengkap dan benar obyek pajak atau perbuatan melanggar hukum (fraud) lainnya. Hal ini merupakan pelanggaran terhadap undang-undang dengan maksud melepaskan diri dari pajak/mengurangi dasar penetapan pajak dengan cara menyembunyikan sebagian dari penghasilannya. Di Indonesia membayar pajak merupakan sebuah kewajiban, sehingga seluruh warga negara harus membayar sesuai dengan peraturan perpajakan. Kerugian penerimaan pajak dari tax evasion sulit untuk diperkirakan.

Hasil penelitian ini tidak sesuai dengan hasil penelitian yang dilakukan oleh Putra et al (2011). Pendapat ini diperkuat dengan hasil deskriptif jawaban responden atas pernyataan kuesioner.

\section{Pengaruh Tingkat Kepatuhan Wajib Pajak Terhadap Penerimaan Pajak.}

Hasil penelitian menujukkan bahwa tingkat kepatuhan Wajib Pajak tidak berpengaruh terhadap penerimaan pajak. Hal ini berarti tingkat kepatuhan Wajib Pajak tidak memiliki kemampuan untuk mempengaruhi penerimaan pajak.

Kepatuhan Wajib Pajak merupakan pemenuhan kewajiban perpajakan yang dilakukan oleh pembayar pajak dalam rangka memberikan kontribusi bagi pembangunan negara. Kepatuhan Wajib Pajak menjadi aspek penting mengingat sistem perpajakan Indonesia menganut self assessment system yang dalam prosesnya secara mutlak memberikan kepercayaan kepada Wajib Pajak. Kewajiban dan hak perpajakan dibagi dalam dua kepatuhan, yaitu kepatuhan formal dan kepatuhan material. Kepatuhan formal dan 
material ini lebih jelasnya diidentifikasi kembali dalam Keputusan Menteri Keuangan No.544/KMK.04/2000. Tingkat kepatuhan Wajib Pajak yang baik akan meningkatkan penerimaan pajak. Sesuai pasal 17C KUP Jis KMK Nomor 544/KMK.04/2000 Direktorat Jenderal Pajak telah mengeluarkan kriteria Wajib Pajak patuh. Wajib Pajak patuh adalah Wajib Pajak yang memenuhi kriteria tertentu yang dapat diberikan pengembalian pendahuluan atas kelebihan pembayaran pajak.

Hasil penelitian ini konsisten dengan penelitian yang dilakukan oleh Adrianti (2013) yang membuktikan bahwa tingkat kepatuhan Wajib Pajak tidak berpengaruh terhadap penerimaan pajak, tetapi bertolak belakang dengan penelitian yang dilakukan oleh Afriyanti (2012) dan Pertiwi (2015). Pendapat ini diperkuat dengan hasil deskriptif jawaban responden atas pernyataan kuesioner.

\section{Pengaruh Self Assessment System Terhadap Penerimaan Pajak.}

Hasil penelitian menujukkan bahwa self assessment system tidak berpengaruh terhadap penerimaan pajak. Hal ini berarti self assessment system tidak memiliki kemampuan untuk mempengaruhi penerimaan pajak.

Kepatuhan diperlukan dalam self assessment system dengan tujuan untuk mencapai penerimaan pajak yang optimal. Sistem pemungutan seperti ini yang mengandalkan pada kepercayaan terhadap Wajib Pajak sangat rentan terhadap penyalahgunaan. Self assessment system dalam praktiknya di Indonesia masih sulit berjalan dengan baik, sehingga Wajib Pajak sulit untuk melaksanakan kewajiban perpajakannya. Hal ini membuat penerimaan pajak di Indonesia masih rendah dan belum cukup optimal dari yang ditargetkan.

Hasil penelitian ini tidak sesuai dengan penelitian yang dilakukan oleh Anggriawan (2015) yang membuktikan bahwa self assessment system berpengaruh terhadap penerimaan pajak. Pendapat ini diperkuat dengan hasil deskriptif jawaban responden atas pernyataan kuesioner.

\section{Pengaruh Kesadaran Wajib Pajak Terhadap Penerimaan Pajak.}

Hasil penelitian menujukkan bahwa kesadaran Wajib Pajak tidak berpengaruh terhadap penerimaan pajak. Hal ini berarti kesadaran Wajib Pajak tidak memiliki kemampuan mempengaruhi penerimaan pajak.

Wajib pajak dikatakan memiliki kesadaran apabila memahami bahwa kewajiban perpajakan harus dilaksanakan sesuai dengan ketentuan yang berlaku dan memahami fungsi pajak untuk pembiayaan negara. Semakin tinggi tingkat kesadaran Wajib Pajak, semakin tinggi pula tingkat penerimaan pajak negara. Kesadaran dan kepedulian sukarela Wajib Pajak sangat sulit untuk diwujudkan seandainya dalam definisi pajak tidak ada frase yang dapat dipaksakan dan yang bersifat memaksa. Masyarakat dituntut melaksanakan kewajiban kenegaraan dengan membayar pajak secara sukarela dan penuh kesadaran demi pembangunan perekonomian. Sampai sekarang kesadaran masyarakat membayar pajak masih belum mencapai tingkat sebagaimana yang diharapkan, namunmasih ada upaya yang dapat dilakukan sehingga Wajib Pajak sadar sepenuhnya untuk membayar pajak.

Hasil penelitian ini konsisten dengan penelitian yang dilakukan oleh Dewi (2013) yang membuktikan bahwa kesadaran Wajib Pajak tidak berpengaruh terhadap penerimaan pajak.

\section{Pengaruh Tingkat Pemahaman Wajib Pajak Mengenai Peraturan Perpajakan Terhadap Penerimaan Pajak.}

Hasil penelitian menujukkan bahwa tingkat pemahaman Wajib Pajak mengenai peraturan perpajakan tidak berpengaruh terhadap penerimaan pajak. Hal ini berarti tingkat pemahaman Wajib Pajak mengenai peraturan perpajakan tidak memiliki kemampuan untuk mempengaruhi penerimaan pajak.

Pengetahuan dan pemahaman peraturan perpajakan yang dimaksud adalah mengerti dan paham tentang ketentuan umum dan tata cara perpajakan yang meliputi bagaimana cara menyampaikan surat pemberitahuan (SPT), pembayaran, tempat pembayaran, denda, dan batas waktu pembayaran atau pelaporan SPT. Rendahnya tingkat pemahaman Wajib Pajak tentang pajak mengakibatkan sikap Wajib Pajak cenderung apatis terhadap pajak yang akhirnya berpengaruh terhadap perilaku atau praktik Wajib Pajak dalam hal kedisiplinan membayar pajak. Oleh sebab itu Wajib Pajak harus memiliki pemahaman mengenai peraturan perpajakan walaupun semakin tinggi atau rendahnya pemahaman Wajib Pajak mengenai peraturan perpajakan tidak mempengaruhi penerimaan pajak. 
Hasil penelitian ini konsisten dengan penelitian yang dilakukan oleh Arisandy (2017) yang membuktikan bahwa tingkat pemahaman Wajib Pajak mengenai peraturan perpajakan tidak berpengaruh terhadap penerimaan pajak, tetapi bertolak belakang dengan penelitian yang dilakukan oleh Dewi (2013). Pendapat ini diperkuat dengan hasil deskriptif jawaban responden atas pernyataan kuesioner.

\section{Pengaruh Persepsi Kualitas Pelayanan Terhadap Penerimaan Pajak.}

Hasil penelitian menujukkan bahwa tingkat pemahaman persepsi kualitas pelayanan berpengaruh terhadap penerimaan pajak. Hal ini berarti persepsi kualitas pelayanan memiliki kemampuan untuk mempengaruhi penerimaan pajak.

Upaya dalam peningkatan penerimaan pajak dapat dilakukan dengan meningkatkan kualitas pelayanan yang baik kepada Wajib Pajak. Peningkatan kualitas pelayanan dapat dilakukan dengan cara meningkatkan kualitas dan kemampuan teknis pegawai dalam bidang perpajakan, perbaikan infrastruktur seperti perluasan tempat pelayanan terpadu (TPT), penggunaan sistem informasi dan teknologi yang dapat memberikan kemudahan kepada Wajib Pajak dalam memenuhi kewajiban perpajakannya. Semakin baik persepsi Wajib Pajak terhadap kualitas pelayanannya, maka semakin tinggi pula tingkat penerimaan pajak. Kualitas pelayanan merupakan tingkat keunggulan untuk memenuhi keinginan Wajib Pajak. Kualitas pelayanan dapat dinilai berdasarkan persepsi Wajib Pajak dengan membandingkan harapan saat menerima layanan dengan pengalaman sebenarnya atas layanan yang diterima.

Hasil penelitian ini konsisten dengan hasil penelitian yang dilakukan oleh Komala (2013) yang membuktikan bahwa persepsi kualitas pelayanan berpengaruh terhadap penerimaan pajak, tetapi bertolak belakang dengan hasil penelitian yang dilakukan oleh Dewi (2013). Pendapat ini diperkuat dengan hasil deskriptif jawaban responden atas pernyataan kuesioner.

\section{Simpulan}

Berdasarkan hasil penelitian tentang pengaruh tax evasion, tingkat kepatuhan Wajib Pajak, self assessment system, kesadaran Wajib Pajak, tingkat pemahaman Wajib Pajak mengenai peraturan perpajakan, dan persepsi kualitas pelayanan terhadap penerimaan pajak, dapat disimpulkan sebagai berikut:

1. Tax evasion tidak berpengaruh terhadap penerimaan pajak, sehingga $\mathrm{H}_{1}$ dalam penelitian ini ditolak. Hal ini ditunjukkan dengan nilai $t_{\text {hitung }}$ sebesar $-0,329$ lebih kecil dari $t_{\text {tabel }}(1,661)$ dengan tingkat signifikansi sebesar 0,743 lebih besar dari $\alpha$ $=0,05$.

2. Tingkat kepatuhan Wajib Pajak tidak berpengaruh terhadap penerimaan pajak, sehingga $\mathrm{H}_{2}$ dalam penelitian ini ditolak. Hal ini ditunjukkan dengan nilai $\mathrm{t}_{\text {hitung }}$ sebesar 0,155 lebih kecil dari $\mathrm{t}_{\text {tabel }}$ $(1,661)$ dengan tingkat signifikansi sebesar 0,877 lebih besar dari $\alpha=0,05$.

3. Self assessment system tidak berpengaruh terhadap penerimaan pajak, sehingga $\mathrm{H}_{3}$ dalam penelitian ini ditolak. Hal ini ditunjukkan dengan nilai $t_{\text {hitung }}$ sebesar $-0,707$ lebih kecil dari $t_{\text {tabel }}(1,661)$ dengan tingkat signifikansi sebesar 0,482 lebih besar dari $\alpha$ $=0,05$.

4. Kesadaran Wajib Pajak tidak berpengaruh terhadap penerimaan pajak, sehingga $\mathrm{H}_{4}$ dalam penelitian ini ditolak. Hal ini ditunjukkan dengan nilai $t_{\text {hitung }}$ sebesar 0,763 lebih kecil dari $t_{\text {tabel }}(1,661)$ dengan tingkat signifikansi sebesar 0,447 lebih besar dari $\alpha$ $=0,05$.

5. Tingkat pemahaman Wajib Pajak mengenai peraturan perpajakan tidak berpengaruh terhadap penerimaan pajak, sehingga $\mathrm{H}_{5}$ dalam penelitian ini ditolak. Hal ini ditunjukkan dengan nilai $t_{\text {hitung }}$ sebesar 1,627 lebih kecil dari $t_{\text {tabel }}(1,661)$ dengan tingkat signifikansi sebesar 0,107 memiliki nilai yang lebih besar dari $\alpha=0,05$.

6. Persepsi kualitas pelayanan berpengaruh terhadap penerimaan pajak, sehingga $\mathrm{H}_{6}$ dalam penelitian ini diterima. Hal ini ditunjukkan dengan nilai $t_{\text {hitung }}$ sebesar 2,368 lebih besar dari $\mathrm{t}_{\text {tabel }}(1,661)$ dengan tingkat signifikansi sebesar 0,020 lebih kecil dari $\alpha$ $=0,05$.

\section{Implikasi}

Implikasi pada penelitian ini didasarkan dari simpulan bahwa pemerintah harus lebih baik dalam mengawasi, mengakomodir, mendistribusikan, dan mengolah dana pajak yang ada, sehingga tercipta suatu keadaan yang harmonis dan stabil dalam mewujudkan pembangunan yang adil dan merata. 


\section{Keterbatasan}

Penelitian yang dilakukan ini mempunyai keterbatasan, sehingga perlu diperhatikan bagi peneliti-peneliti selanjutnya. Adapun keterbatasan penelitian yang ada adalah sebagai berikut:

1. Pengumpulan data dalam penelitian ini menggunakan kuesioner, sehingga peneliti tidak dapat mengontrol responden dalam menjawab instrumen penelitian.

2. Penelitian ini hanya menguji enam faktor yang berhubungan penerimaan pajak sehingga hasilnya kurang tergeneralisasi. Dilihat dari nilai adjusted $R^{2}$, hanya sebesar $13,1 \%$ variabel dependen dipengaruhi oleh variabel independen, sedangkan sisanya $86,9 \%$ dijelaskan oleh variabel lain yang belum ada dalam penelitian ini.

3. Ruang lingkup penelitian ini hanya dilakukan di KPP Pratama Surakarta, sehingga hasil penelitian ini kurang maksimal dan tidak dapat digeneralisasi.

\section{Saran}

Berdasarkan simpulan dan keterbatasan dalam penelitian ini, peneliti memberikan saran sebagai berikut:

1. Pengukuran variabel selain dengan menggunakan kuesioner, perlu diperkuat dengan wawancara sehingga data yang diperoleh dari responden akan lebih valid.

2. Dilihat dari nilai adjusted $R^{2}$, masih terdapat $86,9 \%$ variabel yang belum ada didalam penelitian ini yang mempengaruhi penerimaan pajak. Oleh karena itu, penelitian berikutnya disarankan dapat menambah variabel-variabel lain yang dapat mempengaruhi penerimaan pajak, seperti jumlah Wajib Pajak yang terdaftar, efektivitas administrasi perpajakan, pemeriksaan pajak, dan sanksi pajak.

3. Penelitian selanjutnya disarankan dapat dilakukan di lebih dari dari satu KPP, agar hasil penelitian dapat digeneralisasi dengan ruang lingkup yang lebih luas.

\section{Referensi}

[1] Adrianti, Wella.2013. "Pengaruh Ekstensifikasi pajak dan tingkat kepatuhan wajib pajak orang pribadi terhadap tingkat penerimaan pajak penghasilan pada kantor pelayanan pajak Pratama Kota Tanjung Pinang."
[2] Anggriawan, Angga.2015. "Pengaruh Self Assessment System dan Efektivitas Administrasi Perpajakan terhadap Penerimaan Pajak."

[3] Arisandy, Nelsi.2017. "Pengaruh Pemahaman Wajib Pajak, Kesadaran Wajib Pajak, dan Sanksi Pajak terhadap Kepatuhan Wajib Pajak Orang Pribadi yang Melakukan Kegiatan Bisnis Online di Pekanbaru. "Vol 14, No 1, ISSN 1829-9822.

[4] Chaudry, Imam Sharif dan Farzana Munir.2010. "Determinants of low tax revenue in Pakistan." No 2, Vol 30.

[5] Dewi, Olivia dan Retnaningtyas Widuri.2013. "Faktor-faktor yang mempengaruhi keberhasilan penerimaan pajak daerah kota Tarakan." No 2, Vol 3.

[6] Friskianti dan Handayani.2014."Pengaruh Self Assesment system, keadilan, teknologi perpajakan, dan ketidak percayaan kepada pihak fiskus terhadap tindakan tax evasion." AAJ Volume 3 Nomer 42014 ISSN (Online): 22526765. http://www.journal.unnes,ac,id

[7] Ghozali, Imam. 2011. "Aplikasi Analisis Multivariate Dengan Program IBM SPSS 19, Edisi 5". Badan Penerbit Universitas Diponegoro. Semarang.

[8] Hermawati, Adya.2014. "Analisis Faktor untuk meningkatkan penerimaan pajak penghasilan dan implikasinya terhadap peningkatan penerimaan negara." No 1, Vol 3.

[9] Jones, Douglas H.1982. "Jones: Comment on Statistical Evidence of Discrimination.” No 380, Vol 77. Journal of the American Statistical Association.

[10] Komala, Kirana Cipta dan Maria Goretti.2013. "Pengaruh Kualitas Pelayanan Perpajakan terhadap Kepatuhan Wajib Pajak Badan (Studi pada Kantor Pelayanan Pajak Madya Malang."

[11]Lainutu, Amina.2013. "Pengaruh Jumlah Wajib Pajak Pph 21 terhadap Penerimaan Pph 21 Pada KPP Pratama Manado." No 3, Vol 1.

[12]Mardiasmo. 2013. Perpajakan. Edisi revisi. Yogyakarta: CV Andi.

[13]Pertiwi, Resti M, dkk 2015. "Pengaruh Kepatuhan Wajib Pajak Badan dan Penerbitan Surat Ketetapan Pajak Badan Terhadap Penerimaan Pajak Penghasilan Pasal 25 Badan JAB. ” No 1, Vol 6. 
[14]Philips, et al. 1991. "Assessing Construct Validity in Organizational Research." No 3, Vol 36, pp.421-158.

[15] Putra, Firmanto Rahmad, dkk. 2011. "Dampak Kasus Penggelapan Pajak di Indonesia terhadap Kepatuhan Wajib Pajak di Kota Padang."

[16] Republik Indonesia, Undang-Undang Nomor 28 Tahun 2007 Tentang Ketentuan Umum dan Tata Cara Perpajakan. Republik Indonesia, UndangUndang Nomor 4 Tahun 2012 Pasal 1 Angka 3 tentang Anggaran dan Belanja Negara.

[17]Republik Indonesia, Keputusan Menteri Keuangan Nomor 544/KMK.04/2000.

[18]Resmi, Siti. 2009. “Perpajakan Teori dan Kasus", Jakarta, Salemba Empat.

[19] Sari, Maria M. Ratna dan Ni Nyoman Afriyanti.2012. "Pengaruh Kepatuhan Wajib Pajak Dan Pemeriksaan Pajak Terhadap Penerimaan Pph pasal 25/29 Wajib Pajak Badan pada KPP Pratama Denpasar Timur.” No 1, Vol 7.

[20] Sugiyono. 2010. "Statistika untuk Penelitian". Cetakan ke-16, Bandung, Alfabeta.

[21] Waluyo. 2013. Perpajakan Indonesia. Edisi 11 Buku 1. Jakarta: Salemba Empat.

[22] www.Pajak.go.id 